\title{
OBSERVATIONS ON THE PROBLEM OF DELAYED NIDATION IN SUCKLING MICE
}

\author{
SUZANNE BLOCH \\ Department of Obstetrics and Gynecology, University of Basle, \\ Schanzenstrasse 46, CH-4000, Basle, Switzerland
}

(Received 26th March 1971)

In the course of other studies, observations were made on pregnancy and delayed nidation in suckling mice which seem to explain some differences in the findings of previous authors. The present investigations were carried out with mice of the NMRI strain and of a strain bred at the University Hospital of Basle, here called the B strain. The animals were kept under uniform conditions.

Following a post-partum mating, Kirkham (1916) found that a fifth, and Enzmann, Saphir \& Pincus (1932) that nearly half of such females subsequently became pregnant. Fauvet (1941), on the other hand, stated that in the rat pregnancies are difficult or nearly impossible to obtain from post-partum matings, though we have been unable to confirm this statement. Mantalenakis \& Ketchel (1966) reported a pregnancy rate of $96 \%$ for suckling mice of the Charles River Breeding Laboratories, North Wilmington, Mass., and W. Jöchle (personal communication) found that in one of the best commercial breeding farms for laboratory animals in the U.S.A. the proportion was nearly $100 \%$.

In previous investigations (Bloch, 1948), $25 \%$ of the mice suckling more than two young became pregnant following post-partum mating. These mice had been bought from local dealers and did not belong to a special strain. In the present investigations, we found 131 pregnancies following 165 post-partum matings $(79 \%)$ in the NMRI strain and fifty-six pregnancies after sixty-five matings $(86 \%)$ in the B strain.

These are two especially fertile strains. In our former material, of 1800 litters born, the mean number of young/litter was 6.3 (range 1 to 12). In the NMRI strain, the mean number was 9.75 (range 1 to 18 ) in a total of 1300 litters and in the B strain, a mean number of 12 (range 5 to 18 ) was observed for 184 litters. We suggest that the increased fertility is also reflected by a greater number of suckling females becoming pregnant.

Implantation is usually delayed when the suckled litter is of a certain size. The number of young required for the delay to occur varies according to different authors. Lataste $(1886,1887)$, Daniel (1910) and Kirkham (1916) indicated three or more, while Bindon (1969) noted three to nine, though occasionally one young appeared to be sufficient. In our previous investigations, all females suckling more than two young had delayed nidations. In the present study, all females were suckling six young, i.e. more than are required for delaying nidation, but in the NMRI strain, implantation occurred on time in twenty-five of 131 pregnancies $(19 \%)$, and in twenty of fifty-six pregnancies 
$(36 \%)$ in the B strain. These implantations occurred with litters weighing from 19 to $30 \mathrm{~g}$, whereas formerly delay was found to occur when the weight of the litter exceeded $13 \mathrm{~g}$. The difference between strains indicates that implantation can occur on time in females of the more fertile strains while they are suckling a large litter.

It seems justified to assume that the breeding of more fertile strains in recent years has brought about an increase both in the number of females becoming pregnant and in the number of on-time nidations occurring following a post-partum mating.

The duration of the delay to implantation has been correlated with the number of suckled young (Lataste, 1891, Daniel, 1910; Enzmann et al., 1932), though this appears to be subject to wide individual variation (Brambell, 1937). Kirkham $(1916,1918)$ was unable to confirm this correlation for the mouse, and Hain (1934) and Krehbiel (1941) could not confirm it for the rat. In the present study in which the number of suckled young was uniformly six, we found differences in the length of gestation ranging from 20 to 36 days (NMRI strain) and from 18 to 30 days (B strain). We conclude that, as was the case with our previous animals (Bloch, 1948), there is no relation between the number of the suckled young and the duration of the delay. Nidation takes place when lactation is declining. The onset of this decline is not related to the size of the litter.

\section{REFERENCES}

Bindon, B. M. (1969) Mechanism of the inhibition of implantation in suckling mice. F. Endocr. 44, 357.

BLосн, S. (1948) Zum Problem der Nidationsverzögerung bei der säugenden Maus. Bull. schweiz. Akad. med. Wiss. 4, 309.

BRAmbell, F. W. R. (1937) The influence of lactation on the implantation of the mammalian embryo. Am. F. Obstet. Gynec. 33, 942.

Daniel, J. F. (1910) Observations on the period of gestation in white mice. $\mathcal{F}$. exp. Zool. 33, 942.

Enzmann, E. V., Saphir, N. R. \& Pincus, G. (1932) Delayed pregnancy in mice. Anat. Rec. 54, 345.

FAUVET, E. (1941) Vergleichende Untersuchungen über die Entwicklung und Funktion der Milchdrüsen. VII. Untersuchungen über den Einfluss einer Schwangerschaft auf die Lactation. Arch. Gynäk. 171, 342.

HAIN, A. M. (1934) The effect of suckling on the duration of pregnancy in the rat. F. exp. Biol. 11, 279.

KIRKHAM, W. B. (1916) The prolonged gestation period in suckling mice. Anat. Rec. 11, 31.

KIRKHAM, W. B. (1918) Observations on the relations between suckling and the rate of embryonic development in mice. F. exp. Zool. $27,49$.

KREHBIEL, R. H. (1941) The effect of lactation on the implantation of ova of a concurrent pregnancy in the rat. Anat. Rec. $81,43$.

LATASTE, F. (1886) Recherches de zooéthique sur les mammifères de l'ordre des rongeurs. Act. Soc. Linn. Bordeaux, 40, Sér. 4, T. 10, 293.

Lataste, F. (1887) Notes prises au jour le jour sur différentes espèces de l'ordre des rongeurs. Act. Soc. Linn. Bordeaux, 41, Sér. 5, T. 1, 201.

LATASTE, F. (1891) Des variations de duré de la gestation chez les mammifères et des circonstances qui déterminent ces variations. C. r. Stanc. Soc. Biol. 43, 21.

Mantalenakis, S. J. \& Ketchel, M. M. (1966) Frequency and extent of delayed implantation in lactating rats and mice. $\mathcal{F}$. Reprod. Fert. 12, 391. 